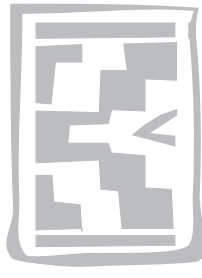

\title{
Molasses as a possible cause of an "endocrine disruptive syndrome" in calves
}

\author{
M.S. MASGORET ${ }^{1}$, C.J. BOTHA ${ }^{1 *}$, J.G. MYBURGH ${ }^{1}$, T.W. NAUDÉ ${ }^{1}$, L. PROZESKY ${ }^{1}$, \\ V. NAIDOO ${ }^{1}$, J.H. VAN WYK ${ }^{2}$, E.J. POOL ${ }^{3}$ and G.E. SWAN ${ }^{1}$
}

\begin{abstract}
MASGORET, M.S., BOTHA, C.J., MYBURGH, J.G., NAUDÉ, T.W., PROZESKY, L., NAIDOO, V., VAN WYK, J.H., POOL, E.J. \& SWAN, G.E. 2009. Molasses as a possible cause of an "endocrine disruptive syndrome" in calves. Onderstepoort Journal of Veterinary Research, 76:209-225

During the mid 1990s a potentially serious, chronic syndrome was reported in well-managed beef and dairy herds from unrelated parts of South Africa. Farmers reported that it manifested as various combinations of decreased production, decreased weaning masses, apparent immune breakdown in previously immunocompetent animals, increased reproductive disorders, various mineral imbalances in non-deficient areas and goitre, noticeable as enlarged thyroid glands. The farmers associated this syndrome with certain batches of sugar cane molasses and molasses-based products. The syndrome was reminiscent of an "endocrine disruptive syndrome".
\end{abstract}

The objective of this study was to evaluate the suspected endocrine disruptive effect of molasses included in cattle feed. Using existing in vitro assays, four batches of molasses syrup were screened for possible inclusion in a calf feeding trial. Two batches were selected for the trial. Thirty-two, 4- to 6-week-old, weaned Holstein bull calves were included in the single phase, three treatment, parallel design experiment. In two of the groups of calves, two different batches of molasses were included in their rations respectively. The control group was fed a ration to which no molasses was added, but which was balanced for energy and mineral content. The mass gain of the calves was recorded over the 6-month study period. The calves were clinically examined every week and clinical pathology parameters, immune responses and endocrine effects were regularly evaluated.

Even though endocrine disrupting effects were detected with the in vitro screening assays, these could not be reproduced in the calves in the experiment. The two batches of molasses utilized in the calf feeding trial did not induce major differences in any of the parameters measured, with the exception of a lower mass gain in one of the molasses-fed groups (Group 1), which tended towards significance.

The results of the study indicate that the two batches of molasses had no endocrine disruptive or immunosuppressive effects in calves.

Keywords: Endocrine disruptive compound, endocrine disruptive syndrome, Holstein calves, sugar cane molasses

* Author to whom correspondence is to be directed. E-mail: christo.botha @up.ac.za

1 Department of Paraclinical Sciences, Faculty of Veterinary Science, University of Pretoria, Private Bag X04, Onderstepoort, 0110 South Africa
2 Ecophysiology Laboratory, Department of Botany and Zoology, University of Stellenbosch, Stellenbosch, 7600 South Africa

3 Department of Medical Bioscience, University of the Western Cape, Bellville, 7535 South Africa 


\section{INTRODUCTION}

During the mid 1990s a chronic, potentially serious syndrome was reported in well-managed beef and dairy herds in various unrelated parts of South Africa, which manifested as combinations of:

- decreased weaning mass;

- apparent immune deficiency/incompetence/ breakdown resulting in calf diarrhoea, mastitis, pneumonia, footrot, verminosis in adult stock and relapses of protozoal diseases in animals considered to be immunocompetent;

- decreased milk yield and loss in condition, particularly of dairy cows;

- increased reproductive disorders with poor conception, resorptions of foetuses and abortions;

- various mineral imbalances, such as copper deficiency in non-deficient areas, selenium deficiency in spite of a kidney selenium excess and high kidney lead concentrations; and

- goitre manifesting as enlarged and/or cystic thyroids in both adults and aborted foetuses.

Although the cause was unknown, farmers related this syndrome to the feeding of certain batches of sugar cane molasses and molasses-based products. This was based on a causal relationship, as all the affected animals were feeding on molasses or molasses-based products. Further support came from the dramatic improvements observed in health and productivity that often followed the withdrawal of the molasses component from the diet.

The reported syndrome shares many similarities with an "endocrine disruptive syndrome" (EDS), a relatively new concept in toxicology that has been well described in humans and in a variety of wildlife species (Colborn, Vom Saal \& Soto 1993; Lamb 1996; Guillette 2000a \& b), but never before in cattle. Although this syndrome is yet to be identified in cattle, it has been predicted that, should it ever occur in cattle, it would be characterized by infertility and immunosuppression (Rhind 2002).

Endocrine disruptive compounds (EDCs) are exogenous substances or mixtures that alter the functions of the endocrine system and consequently cause adverse health effects in an intact organism or its progeny (IPCS - International Programme on Chemical Safety Steering Group 1998). Most EDCs have the ability to act as either hormone agonists or antagonists and/or disrupt production, secretion, transportation, metabolism, receptor binding and excretion of natural hormones which regulate devel- opmental processes and support endocrine homeostasis in the organism (Kavlock, Daston, DeRosa, Fenner-Crisp, Gray, Kaattari, Lucier, Luster, Mac, Maczka, Miller, Moore, Rolland, Scott, Sheehan, Sinks \& Tilson 1996). This ability of EDCs may, amongst others, result in oestrogenic, anti-oestrogenic, androgenic and anti-androgenic effects, which will affect the normal reproductive functions of animals (Li \& Hansen 1996). Endocrine disrupting effects are not confined to effects on steroidal hormones; it has been demonstrated that a number of these environmental agents can alter thyroid hormone levels in humans and animals (Langer, Tajtakova, Fodor, Kocan, Bohov, Michalek \& Kreze 1998; Ishihara, Sawatsubashi \& Yamauchi 2003). Some of the most important compounds included in this classification are: organohalogen compounds, phthalates, bisphenol $A$, alkylphenols and other compounds such as phyto-oestrogens (naturally occurring plant oestrogens) (Colborn, Dumanoski \& Myers 1996). A similar group of compounds, referred to as "immunotoxicants", are pollutants often classified with EDCs and are thought to affect the immune system, mainly by disrupting B- and T-cell homeostasis (Sweeny 2002). For a more extensive discussion a full review is available by Colborn et al. (1996) and Norris \& Carr (2006).

Even though there is a paucity of scientific literature on possible reproductive effects of EDCs in cattle, concerns have been expressed about the potential effects on reproductive health and immune status of farm animals following exposure to a range of natural and synthetic environmental compounds that disrupt normal hormonal homeostasis (Sweeney 2002; Brevini, Cillo, Antonini \& Gandolfi 2005). In the past few years, more evidence regarding the effects of exposure to multiple pollutants on animal production has become available (Meijer, De Bree, Wagenaar \& Spoelstra 1999).

To date there have not been many controlled studies that have confirmed adverse effects of EDCs in cattle, although there is sufficient evidence that there are causal relationships between EDCs and production and reproductive functions of farm animals (Rhind 2005). Furthermore, it is also important to consider the age of the animals at the time of exposure to EDCs. Their impact might be more apparent in the developing foetus and post-natal offspring as many of the normal homeostatic endocrine feedback mechanisms and the immune system are not yet fully developed and there is a greater potential for low dose EDC exposures to exert adverse effects on those systems (Crisp, Clegg, 
Cooper, Wood, Anderson, Baetcke, Hoffman, Morrow, Rodier, Schaeffer, Tovart, Zeeman \& Patel 1998; Sweeny 2002).

Molasses is concentrated syrup of sugar cane consisting of structural sugars, hemicelluloses and minerals, and is usually obtained as a by-product of sugar refining operations. It is an important component of stock feed in South Africa and the rest of the world, serving as a highly fermentable carbohydrate source of energy for growth and maintenance. Moreover, molasses is often included in a ration to improve its palatability, improve rumen microbial activity, increase microbial protein synthesis, reduce dustiness of the ration or act as a binder for pelleting (Perry, Cullison \& Lowrey 1999).

Apart from molasses' ability to deplete copper reserves, attributed to its high sulphur content (Beames 1959; Arthington \& Pate 2002) and a condition known as "molasses toxicity" (McDonald, Edwards, Greenhalg \& Morgan 1995), no other deleterious effects caused by it have been reported in the past. Due to its widespread use in cattle feed, it was considered necessary to ascertain if there was indeed a problem with molasses. Thus, a scientifically controlled study to investigate the suspected toxicity of molasses was essential in order to improve our understanding of the syndrome.

The objectives of this project were threefold:

- to perform an initial screening of four batches of molasses in order to select two potential harmful batches for inclusion in a calf feeding trial;

- to ascertain if specific batches of molasses could reduce growth and production in calves by comparing their mass gain over a 6-month study period; and

- to evaluate the safety of molasses by evaluating clinical and clinico-pathological parameters, immune responses and endocrine effects between the groups of calves.

\section{MATERIALS AND METHODS}

\section{Molasses screening tests}

Molasses syrup samples from four different sugar mills were collected. Two of the sugar mills (Mills 1 and 2) were situated in the southern part of South Africa, where sugar cane is harvested after 2 years of growth-these samples were collected directly from the bulk tanks. The other two sugar mills (Mills 3 and 4) were situated in the northern part of South Africa, where sugar cane is harvested after 12 months-these samples were collected directly from the production line. The four batches of molasses were analysed by the Institute for Soil, Climate and Water (ISCW), Pretoria to determine their chemical and nutrient composition.

As no single in vitro test is able to detect all properties of hormonally active substances a battery of tests (including in vivo tests) were performed to evaluate results (Eertmans, Dhooge, Stuyvaert \& Comhaire 2003). Ethyl acetate and acetone extracts (obtained using analytical grade reagents) of the four batches of molasses were prepared and sent to different laboratories for oestrogenicity, immunotoxicity and thyroid activity assays as described below.

\section{Oestrogenicity assays}

A cell proliferation assay, using a human cancer cell line (MCF-7) to measure oestrogenic activity (Lippman \& Huff 1976), was performed by the Medical Faculty of the Texas A \& M University, USA. The assay was repeated three times and the average calculated.

A "yeast screen" was conducted by the Ecophysiology Laboratory, Department of Botany and Zoology, University of Stellenbosch, South Africa. This test utilizes yeast cells, transfected with the human oestrogen receptor (Gray, Kelce, Wiese, Tyl, Gaido, Cook, Klinefelter, Desaulniers, Wilson, Zacharewski, Waller, Foster, Laskey, Reel, Giesy, Laws, McLachIan, Breslin, Cooper, Di Giulio, Johnson, Purdy, Mihaich, Safe \& Colborn 1997).

In addition, a frog vitellogenin ( $\mathrm{Vtg}$ ) assay was done. In this study, male frog (Xenopus laevis) liver slices were exposed to molasses extracts and the Vtg synthesized by the liver slices, as an indication of oestrogenic activity, was measured by means of radio-immunoassay (Van Wyk, Pool \& Leslie 2003). This assay was performed by the Ecophysiology Laboratory, Department of Botany and Zoology, University of Stellenbosch.

\section{Immunotoxicity screening tests}

Gamma-interferon ( $\gamma$-IFN) was assayed (using a BoviGam ELISA kit), to evaluate the production of $\gamma$-IFN in response to mitogenic stimulation of bovine peripheral blood mononuclear cells, as an indication of immunosuppressive activity (Maue, Waters, Palmer, Whipple, Minion, Brown \& Estes 2004). This assay was performed by the Medical Faculty of the Texas A \& M University, USA. 
The production of interleukin-6 (IL-6), another indicator of immunosuppressive activity, was also measured by the Ecophysiology Laboratory, Department of Botany and Zoology, University of Stellenbosch. After incubation of molasses samples with human blood, the supernatants were assayed for IL-6 concentrations. The difference in IL- 6 response was then calculated and expressed as a percentage recovery using a control sample containing no extract as $100 \%$ recovery. Samples giving recoveries of less than $90 \%$ are considered to indicate inflammatory response suppression (Pool, Johaar, James, Petersen \& Bouic 1998; Pool, Robson, Smith, Van Wyk \& Myburgh 2002).

\section{Thyroid hormone (TH) activity test}

A widely used screening test, the frog metamorphosis assay based on the assessment of tail resorption by $X$. laevis tadpoles, was performed to assess thyroid activity (Eertmans et al. 2003; Turque, Palmier, Le Mevel, Alliot \& Demeneix 2005). In this study the tadpoles were exposed to triiodothyronine $\left(T_{3}\right)$ and thyroxine $\left(T_{4}\right)$ as well as molasses and combinations of $\mathrm{T}_{4}$ and molasses. Tail biopsies from metamorphic tadpoles were collected at 48 and/or $96 \mathrm{~h}$ post-treatment. The level of thyroid hormone receptor $\beta$ (TR $\beta$ ) mRNA was evaluated by means of a reverse transcription-polymerase chain reaction (RT-PCR). This assay was performed by the Ecophysiology Laboratory, Department of Botany and Zoology, University of Stellenbosch.

\section{Calf feeding trial}

\section{Experimental animals, housing and nutrition}

Thirty-two, 4- to 6-week-old, weaned Holstein bull calves of approximately the same mass, supplied by the same rearing facility, were adapted to their new environment over a 4 week period. During the adaptation period they received the same starter ration on which they were reared. The calves were subsequently included in a single phase, three treatment, parallel design experiment. Before inclusion into the study all the animals were clinically examined (normal general appearance and habitus, temperature, respiratory and heart rates, rumen movements, absence of noticeable clinical signs of disease) and clinical pathology parameters (haematology, serum proteins, serum enzyme activities and serum urea nitrogen (SUN) and creatinine) were determined. The calves were weighed before commencement of the trial, ranked from the heaviest to the lightest and sorted into replicates of three animals each. Within each replicate the calves were randomly allocated, by means of a table of random numbers, to the treatment groups.

The calves $(n=32)$ were allocated to three groups and each group was fed one of the following rations at $3 \%$ body mass:

Group 1: a ration containing $6 \%$ of molasses ("as is" basis) from Mill 1 ( $n=11$ )

Group 2: $\quad$ a ration containing $6 \%$ of molasses ("as is" basis) from Mill $4(n=10)$

Control Group: a ration to which no molasses was added, but approximately $3 \%$ fermentable sugar (sucrose, glucose and fructose) and minerals (mainly potassium, magnesium and sulphate) equivalent to that of the national average for molasses (as supplied by the Sugar Milling Research Institute (SMRI), University of KwaZulu-Natal, Durban) were added to it to compensate for the mineral and energy content of molasses $(n=$ 11).

Eragrostis hay (both E. curvula and E. tef) was also available ad libitum and the calves had free access to potable municipal water.

The calves were weighed weekly and the amount of the ration to be fed was adjusted accordingly. The rations were balanced by an independent nutritionist to ensure that they were equivalent in all aspects. The three different rations were mixed separately in batches of one ton each. The mixer used for this procedure was cleaned of all loose material before mixing and the control ration without molasses was always mixed first followed by the two molassescontaining rations.

The calves were individually housed, in pens, at the University of Pretoria's Biomedical Research Centre, Onderstepoort so that each calf only had access to its own feed. Animals were allowed access to an adjacent communal camp, for approximately $6 \mathrm{~h}$ a day, during weekdays for exercise and socialization.

\section{Feed and water analysis}

Samples of each batch of feed (eight in total) were collected and submitted for complete feed analyses to UP Nutrilab, Department of Animal and Wildlife Sciences, Faculty of Natural and Agricultural Sciences, University of Pretoria. The analyses were 
performed according to the laboratory's official standard operating procedures (Giron 1973; Association of Official Analytical Chemists 2000).

Water samples were collected at commencement of the trial and submitted to the ISCW for ICP-MS analysis.

\section{Clinical examination}

The animals were observed daily for any abnormalities. Diarrhoea was included as part of the clinical signs, when:

- calves exhibited mild diarrhoea (semi-formed to soft) on 3 or more days during the specific week;

- calves exhibited moderate diarrhoea (soft to watery) on 2 or more days during the specific week; and

- calves exhibited severe diarrhoea (watery) on one or more occasions during the specific week.

The calves were clinically examined every week. However, daily clinical examinations were performed whenever an animal's physical condition deteriorated. Due to persistent diarrhoea in a number of calves, faecal samples were collected from six animals on Day 90 of the trial and screened for coccidial oocysts and helminth eggs and submitted to the Department of Veterinary Tropical Diseases, Faculty of Veterinary Science, University of Pretoria for bacterial culture. Faecal samples were also sent for virus particle identification by electron microscopy (EM) to the Department of Anatomy and Physiology, Faculty of Veterinary Science, University of Pretoria

\section{Body mass}

The animals were weighed weekly on a calibrated digital built-in floor scale and the weekly mass gain was calculated.

\section{Clinical pathology}

Clinical pathology parameters were assessed before the commencement of the trial and on Days 120 and 148 after the experiment commenced. The following parameters were determined by the Clinical Pathology Laboratory, Faculty of Veterinary Science, University of Pretoria:

- Haematology (red cell count, white cell count [including differential count], thrombocyte count, haematocrit);

- Serum proteins (total serum proteins, albumin and globulins);
- Serum enzyme activities (alkaline phosphatase [ALP], Y-glutamyltransferase [GGT], lactate dehydrogenase [LDH] and aspartate aminotransferase [AST]); and

- Serum nitrogenous compounds (urea \& creatinine).

\section{Thyroid hormone analyses}

The animals were bled once before commencement of the trial (Day 0) and three times during the trial to measure triiodothyronine $\left(T_{3}\right)$ and thyroxine $\left(T_{4}\right)$ concentrations. The latter were at 1 month (Day 29), at 3 months (Day 86) and at 5 months (Day 148). The analyses were performed by the staff of the Endocrinology Laboratory, Faculty of Veterinary Science using a Coat-A-Count Total $\mathrm{T}_{3} / \mathrm{T}_{4}$ method (Diagnostic Products Corporation, USA).

\section{Testosterone analysis}

Serum of the 32 animals, bled on Day 154 of the feeding trial, was submitted to the Reproduction Laboratory, Faculty of Veterinary Science, University of Pretoria, for determination of total testosterone concentrations. The analysis was performed by means of a Coat-A-Count Total Testosterone radioimmunoassay (Diagnostic Products Corporation, USA).

\section{Tests to assess immune status of the calves}

All the animals, which had been vaccinated at 4 weeks of age against Mannheimia haemolytica, infectious bovine rhinotracheitis (IBR) and bovine viral diarrhoea (BVD) with Bovi-Tect PI® (Intervet SA (Pty), Ltd) at the rearing facility, were bled on Day 120 of the feeding trial to assess their immune competence. Serum samples were submitted to the Department of Veterinary Tropical Diseases, Faculty of Veterinary Science for an indirect fluorescent antibody (FA) test for IgG antibodies against IBR.

Serum samples from Day 120 were also sent to the ARC-Onderstepoort Veterinary Institute (OVI) to determine Brucella antibody titres using the complement fixation test (CFT). Following blood collection, the calves were immunized (on Day 120) with Brucella abortus Strain 19 vaccine $₫$, (Onderstepoort Biological Products). Four weeks later blood was again collected and the CFT repeated to measure antibody titres in all the experimental animals (Coetzer, Thomson \& Tustin 1994).

A "Brucella protein allergen skin test" was performed in all the calves on Day 170 of the trial. An 
area of the skin of the neck was selected in each animal and its thickness was measured using a calliper.

Animals were then injected intradermally with Brucellergene OCB $囚$ (Synbiotics Corporation), a Brucella protein allergen. The skin thickness was again measured $72 \mathrm{~h}$ later (Day 173) to evaluate the inflammatory reaction against the allergen.

A "Lymphocyte transformation test" was done immediately before commencement of the feeding trial and after 4 months (Day 120 of the trial), to ascertain the immune competence of the animals. The lymphocytes were challenged with the mitogen, Concanavilin A (Con-A) (Van Kleef, MacMillan, Gunter, Allsop, Shkap \& Brown 2000). An unstimulated animal was used as control. This test was performed by the Division of Molecular Biology, OVI.

Immunoglobulin $G(\lg G)$ and Immunoglobulin $M$ (IgM) were first measured at the beginning of the trial to determine a basal level. The animals were bled again at 4 months (Day 120) and at 5 months (Day 154), before and after the immunization with Brucella abortus Strain 19 vaccine, to determine their immunoglobulin titres and therefore their immune competence. The titres were determined by the Clinical Pathology Laboratory, Faculty of Veterinary Science, University of Pretoria.

\section{Post-mortem analyses}

The animals were slaughtered during Week 26 of the trial at an approved abattoir. The carcass mass of each animal was recorded at slaughter.

Samples of various organs or tissues were collected at necropsy. These included: cerebrum, cerebellum, midbrain, brainstem, heart, lung, rumen wall, small and large intestine, several lymph nodes, spleen, liver, kidney, testis, thyroid gland, pancreas, thymus and adrenal gland.

Samples for histopathology (10 mm thickness) were collected and fixed in $10 \%$ buffered formalin. The tissues were routinely processed, embedded in paraffin wax, cut and mounted on glass slides, and stained with haematoxylin and eosin. The organs were evaluated macroscopically and the histopathology slides were viewed under a light microscope by two independent pathologists.

Various tissue samples were submitted to the Bacteriology Division, OVI, for Brucella culture. The following tissues were collected: retropharyngeal-, superficial inguinal and prescapular lymph nodes, tonsils, spleen, testis and epididymus. Bacterial culture was done using standard techniques (Alton, Jones, Angus \& Verger 1988).

Liver samples (100-200 g) were also collected and submitted to the UP Nutrilab for copper (Cu), iron $(\mathrm{Fe})$, manganese $(\mathrm{Mn})$ and zinc $(\mathrm{Zn})$ determination by means of atomic absorption spectrophotometry (Giron 1973).

\section{Statistical analyses}

The data were captured and arranged in animals per replicate. Various statistical analyses were performed by Statistical Consultation Service, Potchefstroom Campus of the University of North-West. All statistical calculations were performed using a statistical programme (StatSoft. Inc. 2005). The significance level was set at $P<0.05$. Clinical significance was based on the partial eta-square. An eta-square value of 0.14 can be viewed as a large effect (Cohen 1988).

One-way analysis of variance (ANOVA) on experimental groups was utilized to test for differences in carcass masses, the Brucella complement fixation test and testosterone concentration.

Repeated measures analyses were done on weekly mass gains, $T_{3}, T_{4} \lg G$ and lgM levels. These were followed by two-way ANOVA on groups within block-replicates. Tukey multiple comparisons were performed to compare groups or Bonferroni multiple comparisons to compare different times over all groups.

A two-way ANOVA on groups within block-replicates was used for monthly mass gain, the Brucella skin test and the lymphocyte transformation test.

\section{RESULTS}

\section{Molasses screening tests}

The selection of the molasses to be used in the calf feeding trial was based on the laboratory screening tests (Table 1) since no major differences were noticeable in the chemical and nutritional composition of the four batches (Table 2). Molasses from Mill 1 showed the highest oestrogenic activity based on the MCF-7 assay as well as in the yeast screen and a marked immunosuppressive activity with the $\gamma$ IFN assay. Molasses from Mill 4 showed the highest immunosuppressive effect with the IL- 6 assay and a high TH activity. Based on the results obtained with these laboratory screening tests, molasses from 
TABLE 1 Screening tests results

\begin{tabular}{|c|c|c|c|c|c|c|}
\hline Test* & MCF-7 & Yeast screen & Vtg & $\gamma$-IFN & IL-6 & $\begin{array}{l}\text { Thyroid } \\
\text { toxicity }\end{array}$ \\
\hline Laboratory & Texas & Stellenbosch & Stellenbosch & Texas & Stellenbosch & Stellenbosch \\
\hline $\begin{array}{l}\text { Mill } 1 \text { blank } \\
\text { Mill } 1 \text { sample }\end{array}$ & 2729 ppt & $\begin{array}{l}0.5 \text { OD } \\
3.0 \text { OD }\end{array}$ & $\begin{array}{l}7 \mu \mathrm{g} / \mathrm{ml} \\
2-12 \mu \mathrm{g} / \mathrm{ml}\end{array}$ & 0.3 OD & $92 \%$ & 0.23 units \\
\hline $\begin{array}{l}\text { Mill } 2 \text { blank } \\
\text { Mill } 2 \text { sample }\end{array}$ & $1090 \mathrm{ppt}$ & $\begin{array}{l}0.5 \mathrm{OD} \\
0.6 \mathrm{OD}\end{array}$ & $\begin{array}{l}\text { Negative } \\
\text { Negative }\end{array}$ & $1.1 \mathrm{OD}$ & $\begin{array}{r}>90 \% \\
89 \%\end{array}$ & 0.18 units \\
\hline $\begin{array}{l}\text { Mill } 3 \text { blank } \\
\text { Mill } 3 \text { sample }\end{array}$ & $1090 \mathrm{ppt}$ & $\begin{array}{l}0.6 \mathrm{OD} \\
1.5 \mathrm{OD}\end{array}$ & $\begin{array}{l}2 \mu \mathrm{g} / \mathrm{ml} \\
40 \mu \mathrm{g} / \mathrm{m} \ell\end{array}$ & $1.3 \mathrm{OD}$ & $73 \%$ & 0.21 units \\
\hline $\begin{array}{l}\text { Mill } 4 \text { blank } \\
\text { Mill } 4 \text { sample }\end{array}$ & $467 \mathrm{ppt}$ & $\begin{array}{l}0.6 \mathrm{OD} \\
1.3 \mathrm{OD}\end{array}$ & $\begin{array}{l}2 \mu \mathrm{g} / \mathrm{ml} \\
5-25 \mu \mathrm{g} / \mathrm{ml}\end{array}$ & $1.35 \mathrm{OD}$ & $68 \%$ & 0.32 units \\
\hline
\end{tabular}

* Maximum results in bold text

TABLE 2 Chemical and nutritional analyses of molasses

\begin{tabular}{|c|c|c|c|c|c|}
\hline Nutritional data & Mill 1 & Mill 2 & Mill 3 & Mill 4 & $\begin{array}{l}\text { National } \\
\text { average* }\end{array}$ \\
\hline $\begin{array}{l}\text { Dry solids (\%) } \\
\text { Fructose (\%) } \\
\text { Glucose (\%) } \\
\text { Sucrose (\%) } \\
\text { Starch (ppm) }\end{array}$ & $\begin{array}{l}77.05 \\
6.7 \\
4.3 \\
27.7 \\
1342\end{array}$ & $\begin{array}{l}74.89 \\
7.7 \\
5.2 \\
27.6 \\
1586\end{array}$ & $\begin{array}{l}81.45 \\
9.5 \\
7.4 \\
28.1 \\
922\end{array}$ & $\begin{array}{l}79.03 \\
8.9 \\
6.5 \\
27.6 \\
542\end{array}$ & $\begin{array}{l}7.4 \\
5.2 \\
31.3 \\
1900\end{array}$ \\
\hline \multicolumn{5}{|c|}{ Elements (mg/kg) on an "as is" basis } & \\
\hline $\begin{array}{l}\text { Arsenic } \\
\text { Beryllium } \\
\text { Boron } \\
\text { Cadmium } \\
\text { Chromium } \\
\text { Cobalt } \\
\text { Copper } \\
\text { Lead } \\
\text { Lithium } \\
\text { Mercury } \\
\text { Molybdenum ** } \\
\text { Nickel } \\
\text { Selenium } \\
\text { Tin } \\
\text { Uranium } \\
\text { Vanadium } \\
\text { Zinc }\end{array}$ & $\begin{array}{l}0 \\
0.0166 \\
8.5466 \\
0.3039 \\
0 \\
0.614 \\
2.5636 \\
1.1576 \\
0.1509 \\
1.1796 \\
<0.01 \\
1.8036 \\
3.8844 \\
0.0937 \\
0 \\
0 \\
13.9484\end{array}$ & $\begin{array}{l}0 \\
0.0188 \\
12.1501 \\
0.3229 \\
0 \\
1.0301 \\
2.6086 \\
1.4927 \\
0.1034 \\
0.9608 \\
- \\
3.1614 \\
3.6116 \\
0.2538 \\
0 \\
0 \\
16.4702\end{array}$ & $\begin{array}{l}1.1029 \\
0.027 \\
21.615 \\
0.3215 \\
0.1351 \\
1.6929 \\
3.179 \\
0.9294 \\
0.1587 \\
0.9263 \\
- \\
4.2833 \\
3.6971 \\
0.1771 \\
0 \\
0 \\
14.3986\end{array}$ & $\begin{array}{l}2.3084 \\
0.022 \\
9.8574 \\
0.324 \\
0.2778 \\
1.7604 \\
4.8766 \\
1.24 \\
0.1302 \\
1.3735 \\
0.17 \\
13.3637 \\
3.8244 \\
0.0816 \\
0 \\
0 \\
17.598\end{array}$ & \\
\hline
\end{tabular}

* Information supplied by the Sugar Milling Research Institute

** Analysed by Central Analytical Laboratories, Pretoria

from Mills 1 and 4 was selected to be used in the feeding trial.

\section{Calf feeding trial}

\section{Feed and water analysis}

The mean values of the feed analyses of the eight samples collected during the trial were calculated for each group. The results are presented in Table
3. There were no major differences in the composition of the rations fed to the three groups. Water analysis results confirmed that all values were within normal ranges.

\section{Clinical examination}

Bouts of diarrhoea were observed in all the calves before and during the first half of the feeding experiment (Fig. 1). However, Group 2 had a higher 
TABLE 3 Feed and mineral analyses on an "as is" basis

\begin{tabular}{|c|c|c|c|}
\hline & Group 1 & Group 2 & Control Group \\
\hline & \multicolumn{3}{|l|}{ Mean \pm SD } \\
\hline $\begin{array}{l}\text { DM }(\mathrm{g} / 100 \mathrm{~g}) \\
\text { Moist }(\mathrm{g} / 100 \mathrm{~g}) \\
\text { Ash }(\mathrm{g} / 100 \mathrm{~g}) \\
\text { CP }(\mathrm{g} / 100 \mathrm{~g}) \\
\text { C Fat }(\mathrm{g} / 100 \mathrm{~g}) \\
\text { ME }(\mathrm{MJ} / \mathrm{kg})\end{array}$ & $\begin{array}{r}87.2 \pm 0.40 \\
12.8 \pm 0.40 \\
5.5 \pm 0.32 \\
12.7 \pm 0.54 \\
3.87 \pm 1.37 \\
15.93 \pm 0.34\end{array}$ & $\begin{aligned} 87.1 & \pm 0.44 \\
12.8 & \pm 0.44 \\
5.5 & \pm 0.42 \\
12.8 & \pm 0.70 \\
3.8 & \pm 1.23 \\
15.9 & \pm 0.26\end{aligned}$ & $\begin{array}{r}88.0 \pm 0.43 \\
11.9 \pm 0.43 \\
6.6 \pm 0.52 \\
12.5 \pm 0.56 \\
3.7 \pm 1.26 \\
15.7 \pm 0.40\end{array}$ \\
\hline $\begin{array}{l}\mathrm{Ca}(\mathrm{g} / 100 \mathrm{~g}) \\
\mathrm{P}(\mathrm{g} / 100 \mathrm{~g}) \\
\mathrm{Mg}(\mathrm{g} / 100 \mathrm{~g}) \\
\mathrm{Cu}(\mathrm{mg} / \mathrm{kg}) \\
\mathrm{Fe}(\mathrm{mg} / \mathrm{kg}) \\
\mathrm{Zn}(\mathrm{mg} / \mathrm{kg}) \\
\mathrm{Mn}(\mathrm{mg} / \mathrm{kg}) \\
\mathrm{K}(\mathrm{g} / 100 \mathrm{~g}) \\
\mathrm{Na}(\mathrm{g} / 100 \mathrm{~g})\end{array}$ & $\begin{aligned} 0.77 & \pm 0.05 \\
0.38 & \pm 0.06 \\
0.19 & \pm 0.03 \\
31.01 & \pm 6.09 \\
356.11 & \pm 99.08 \\
121.90 & \pm 8.55 \\
71.29 & \pm 14.98 \\
0.99 & \pm 0.11 \\
0.17 & \pm 0.05\end{aligned}$ & $\begin{aligned} 0.78 & \pm 0.08 \\
0.37 & \pm 0.06 \\
0.19 & \pm 0.03 \\
30.76 & \pm 4.34 \\
357.37 & \pm 93.47 \\
125.11 & \pm 9.81 \\
62.92 & \pm 13.11 \\
1.04 & \pm 0.06 \\
0.22 & \pm 0.07\end{aligned}$ & $\begin{aligned} 0.82 & \pm 0.07 \\
0.46 & \pm 0.06 \\
0.22 & \pm 0.03 \\
34.86 & \pm 9.58 \\
340.86 & \pm 62.27 \\
140.72 & \pm 22.01 \\
113.78 & \pm 59.52 \\
1.32 & \pm 0.18 \\
0.19 & \pm 0.07\end{aligned}$ \\
\hline
\end{tabular}

$\mathrm{SD}=$ Standard deviation

number of animals with diarrhoea, but this did not affect their mass gain. No viral particles were noticed with the EM scan and no bacterial pathogens were cultured in any of the samples. The diarrhoeal fluid was also negative for coccidial oocysts and helminth eggs.

Calf 8 from Group 1 was hospitalized on Day 93 of the trial due to severe persistent diarrhoea; it made an uneventful recovery and was returned to the group. Four months after the commencement of molasses feeding, one of the calves from the control group (Calf 5) developed an abomasal displacement which was corrected surgically. When the displacement re-occurred on Day 162 of the trial, the calf was slaughtered in the abattoir. Another animal from Group 1 (Calf 28) developed an upper respiratory tract infection on Day 157, it was treated with an antibacterial agent [danofloxacin, Advocin $®$, Pfizer Laboratories (Pty) Ltd] and a non-steroidal anti-inflammatory drug [flunixin meglumine, Cronyxin $\circledast$, Kyron Laboratories (Pty) Ltd.] and subsequently recovered.

\section{Body mass}

The mean live body mass of the three groups are depicted in Fig. 2. No significant differences between the groups were noticed throughout the trial.

The weekly mass gain of each animal was calculated against its initial mass at the beginning of the trial (Fig. 3). Average weekly mass gains of the two molasses-fed groups were compared with those of the Control Group (Fig. 4). A notable lower mean mass gain, although not statistically significant, occurred in Group 1 compared with Group 2 and the Control Group. However, when the experimental error was corrected (due to the large differences in body mass between different replicates) the monthly mass gain was only statistically significantly $(P=$ 0.025 ) lower in Group 1 at 4 months following molasses feeding and at no other time.

\section{Clinical pathology}

The mean of the clinical pathology parameters was calculated for each group (Tables 4 and 5). All the parameters fluctuated within or near normal ranges.

\section{Thyroid hormone analyses}

The results of the $T_{3}$ and $T_{4}$ analyses were plotted (Fig. 5 and 6). The mean $T_{3}$ concentrations of the three groups showed similar curves. Group 1 showed a slightly lower mean $\mathrm{T}_{4}$ concentration compared to the other two groups at 3 months after commencement of molasses feeding. However, no statistical significant difference could be demonstrated. In the Control Group an appreciable decrease in mean $\mathrm{T}_{4}$ concentrations occurred from the initial bleeding before the molasses feeding commenced, up to 3 months of molasses feeding.

\section{Testosterone analysis}

There were no significant differences amongst the groups with regard to their mean testosterone concentrations (Table 6). 

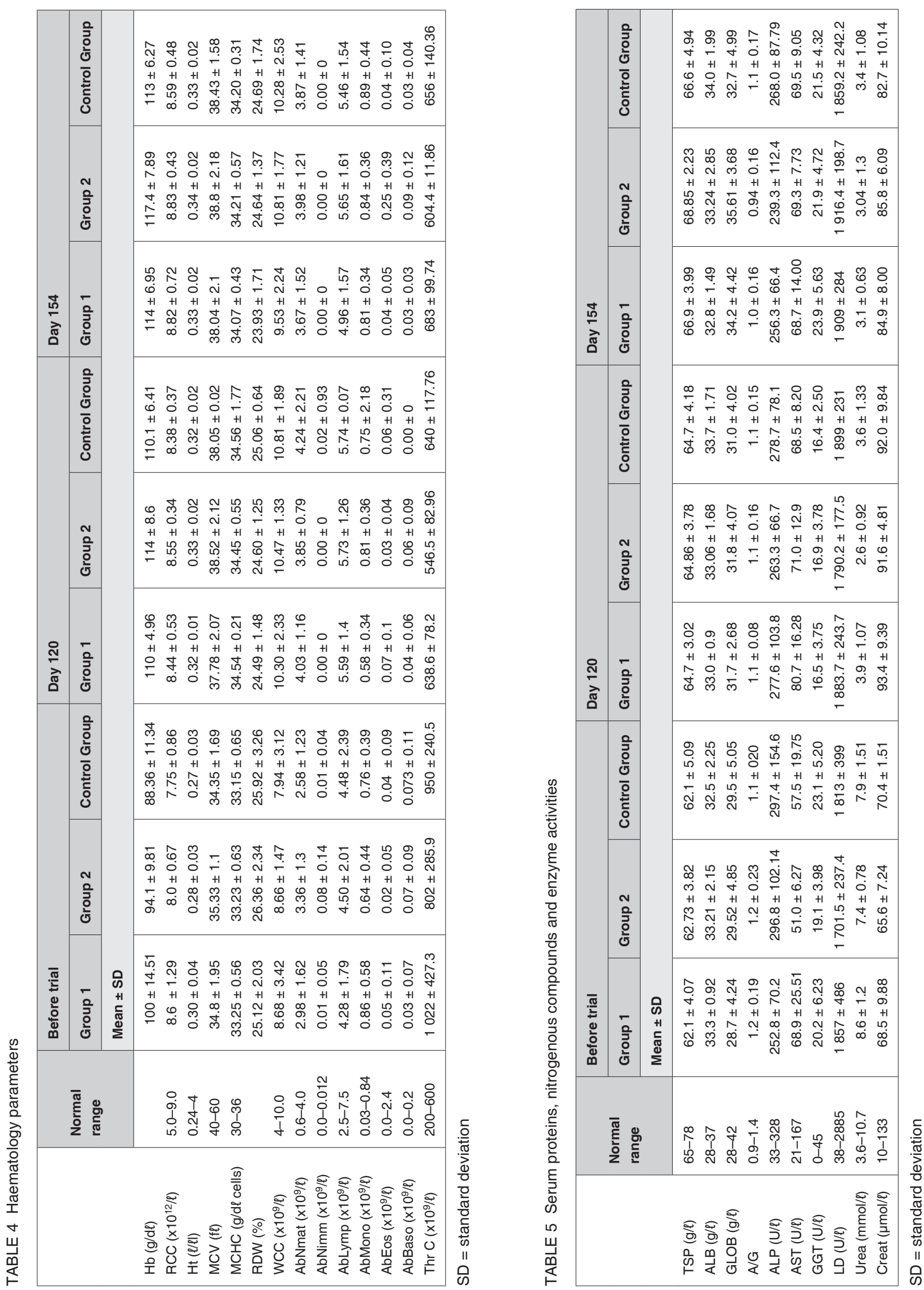


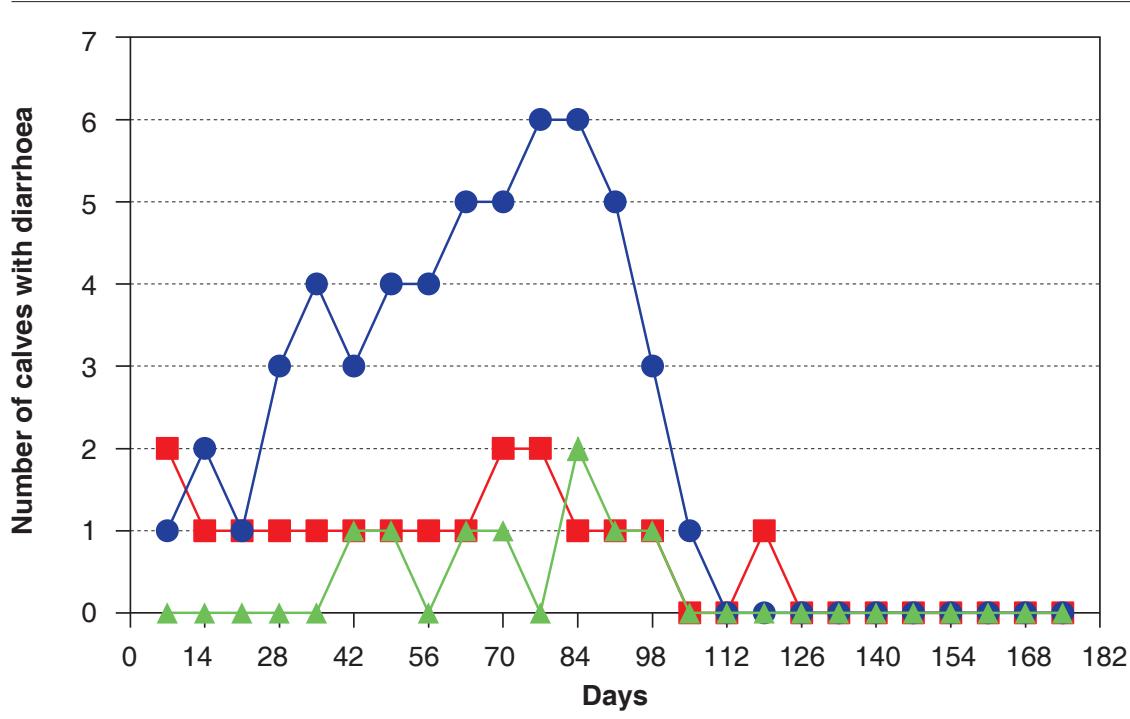

FIG. 1 Diarrhoea in calves from the three experimental groups
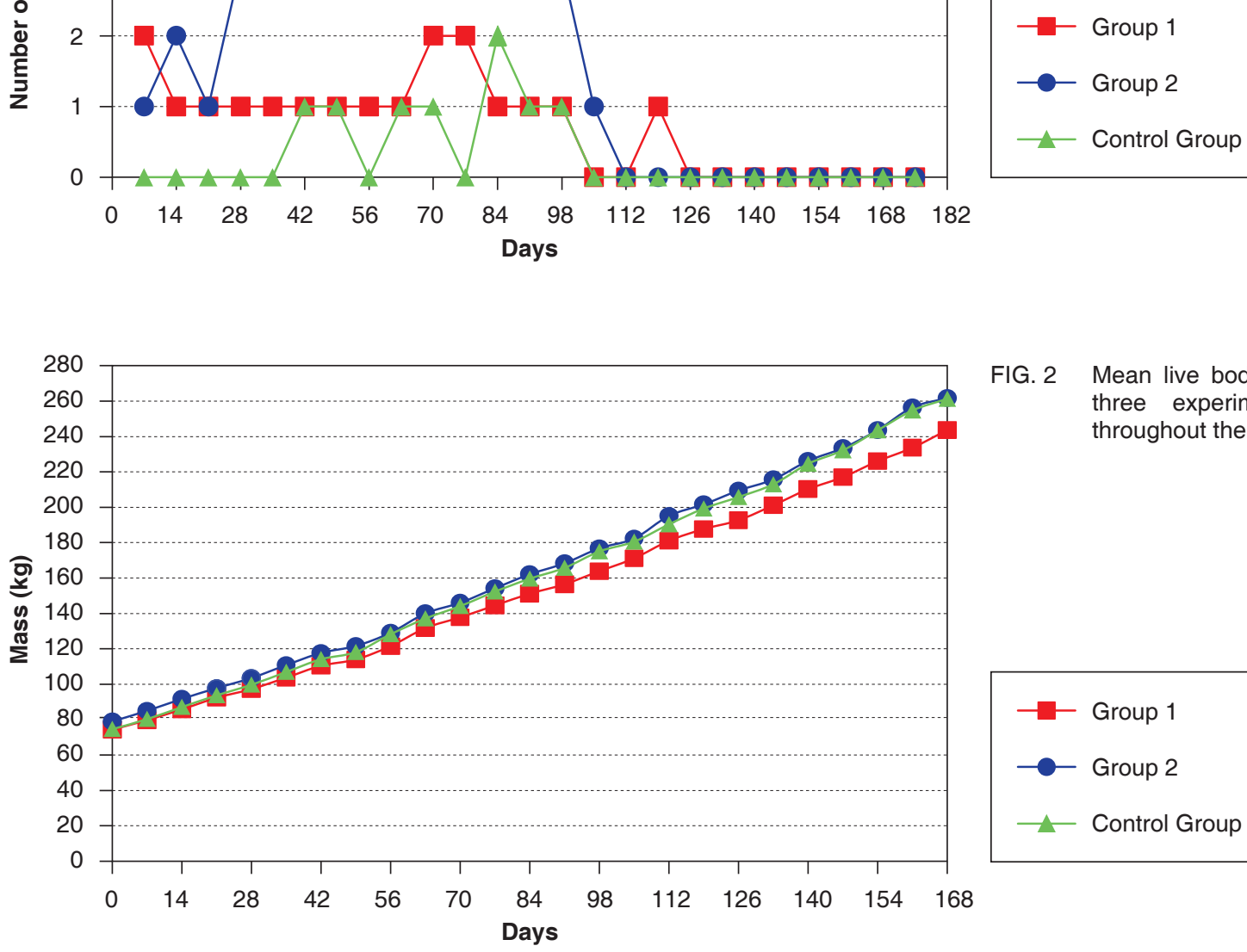

FIG. 2 Mean live body mass of the three experimental groups throughout the trial
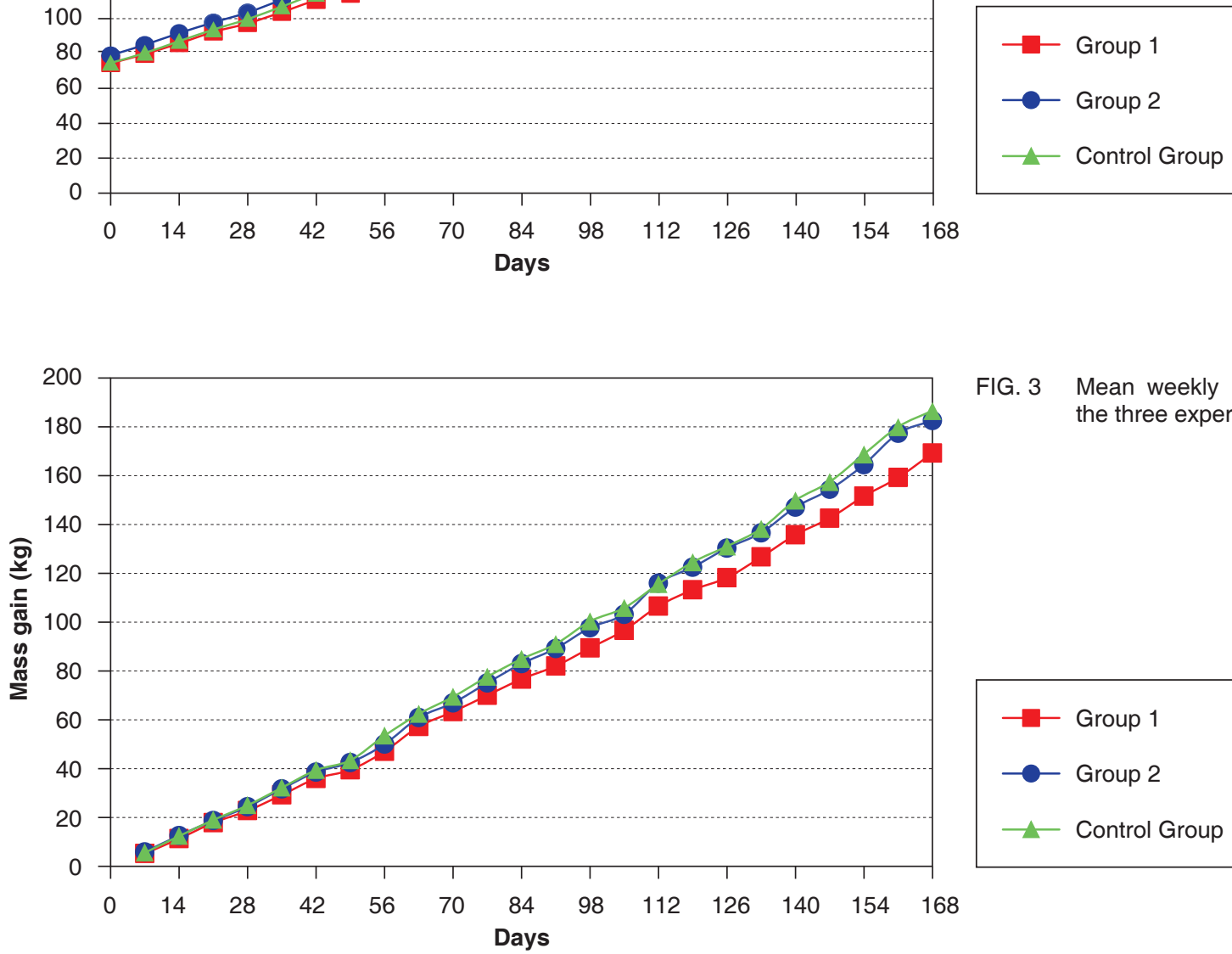

FIG. 3 Mean weekly mass gains of the three experimental groups 


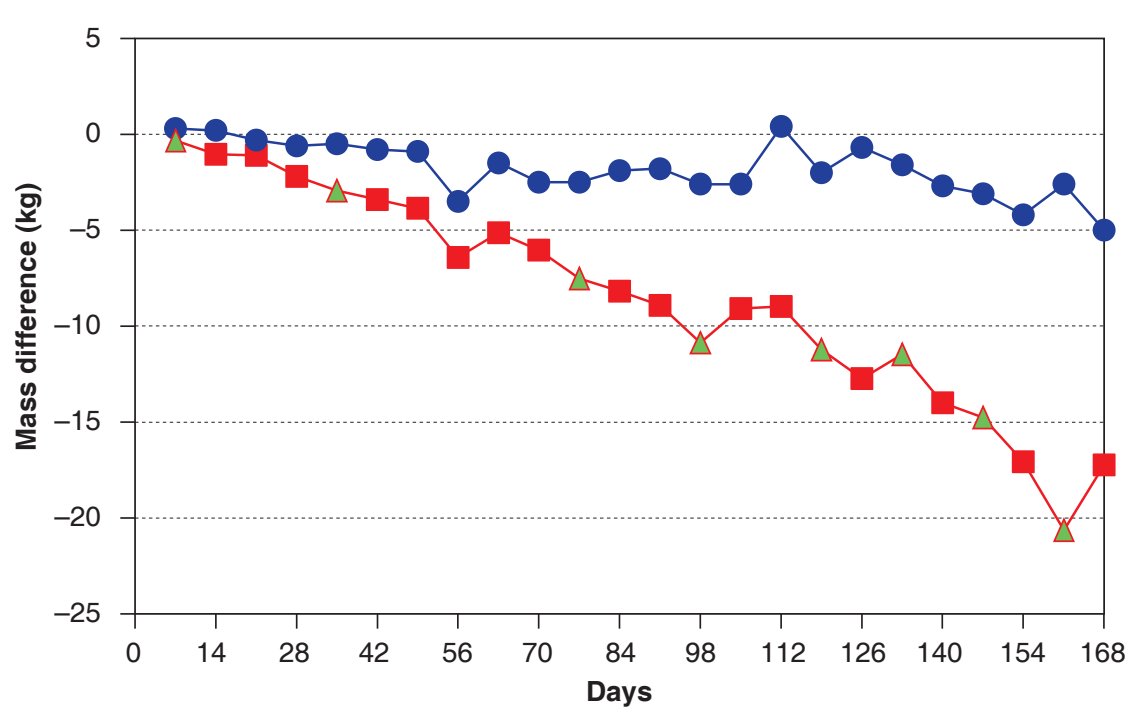

FIG. 4 Average weekly mass gains of the two molasses-fed groups compared to those of the Control Group (green triangle indicates a new batch of feed)

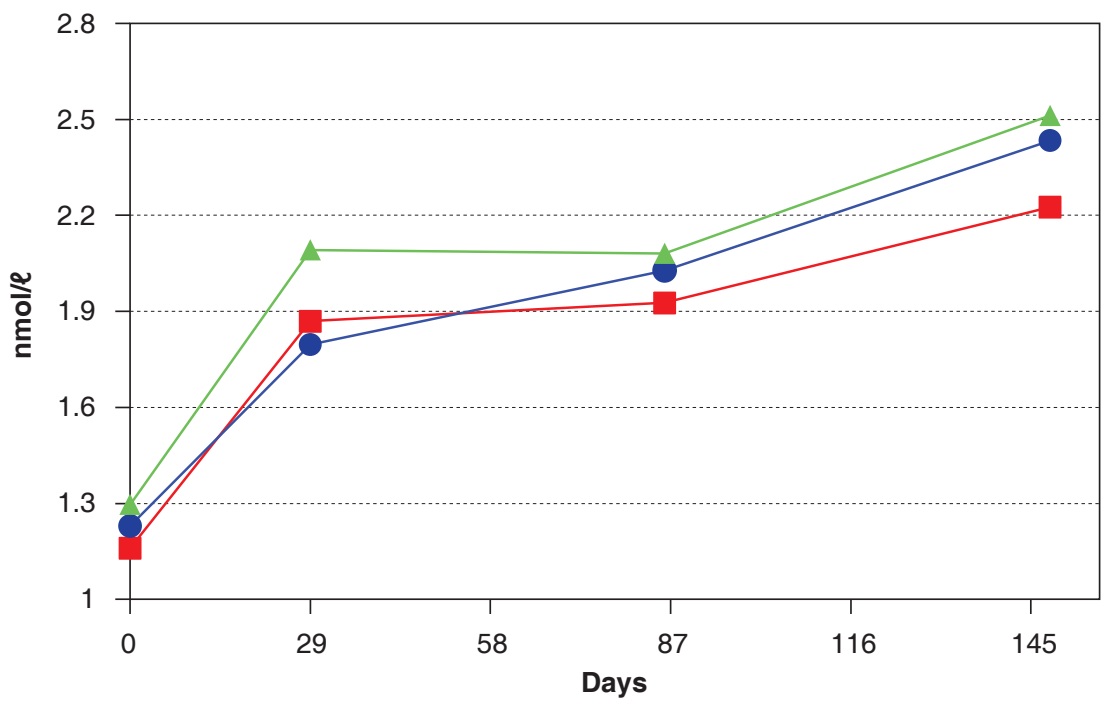

FIG. 5 Mean triiodothyronine $\left(\mathrm{T}_{3}\right)$ concentrations of the three experimental groups at Days 0 , 29,86 and 148 of the feeding trial
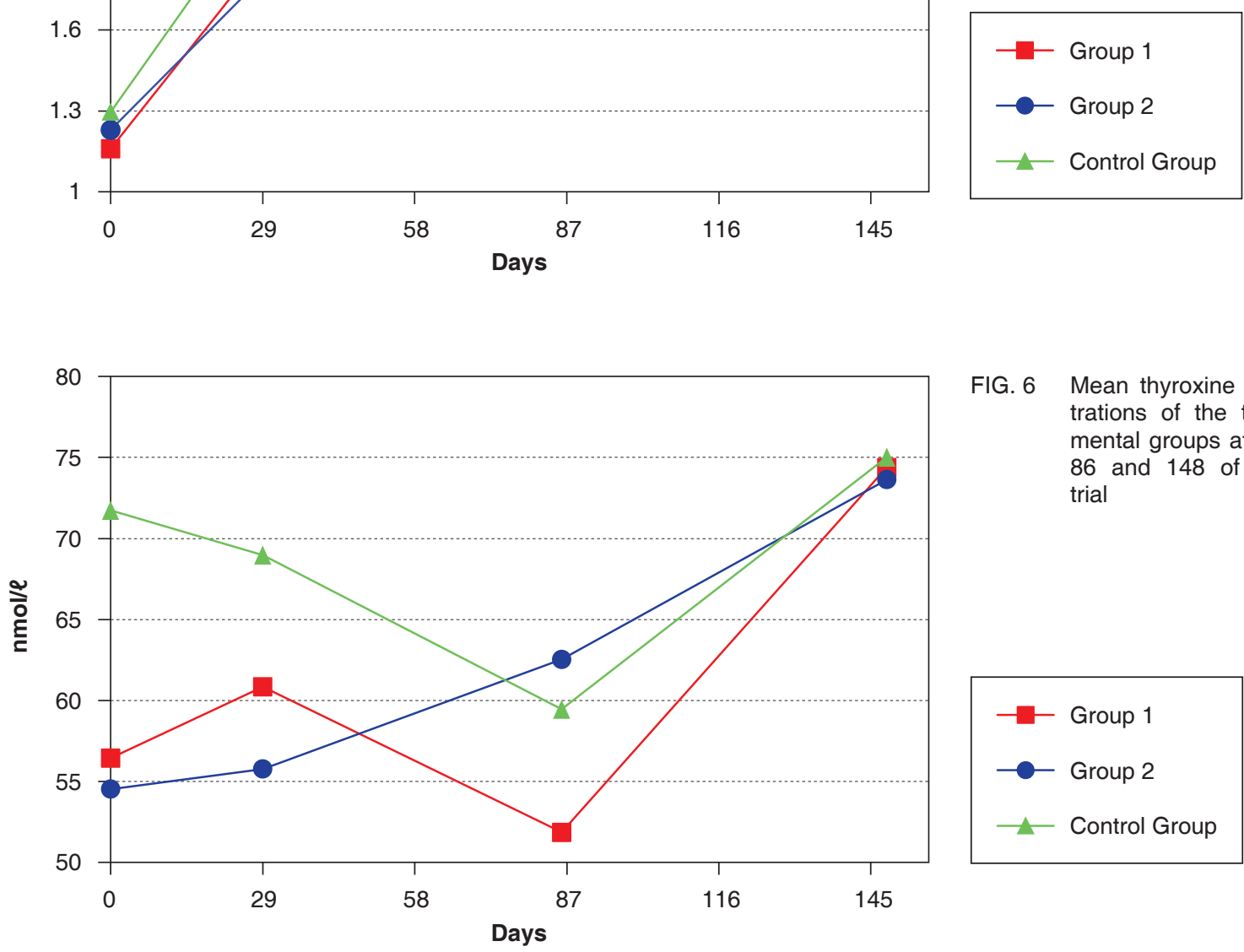

FIG. 6 Mean thyroxine $\left(T_{4}\right)$ concentrations of the three experimental groups at Days 0, 29, 86 and 148 of the feeding trial

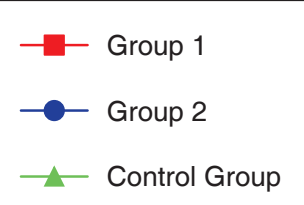


Molasses as cause of "endocrine disruptive syndrome" in calves

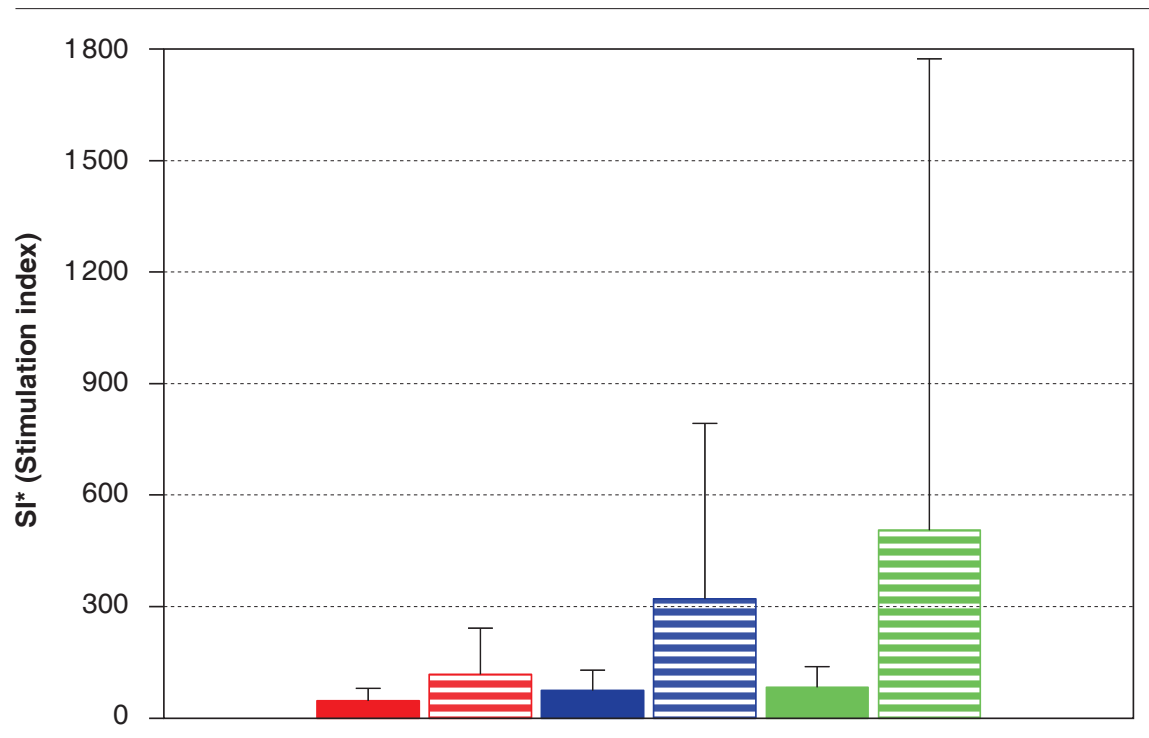

FIG. 7 Results of the lymphocyte transformation test of the three experimental groups before and after 4 months of molasses feeding

Group 1: Before

E Group 1: After

Group 2: Before

E Group 2: After

Control Group: Before

E Control Group: After

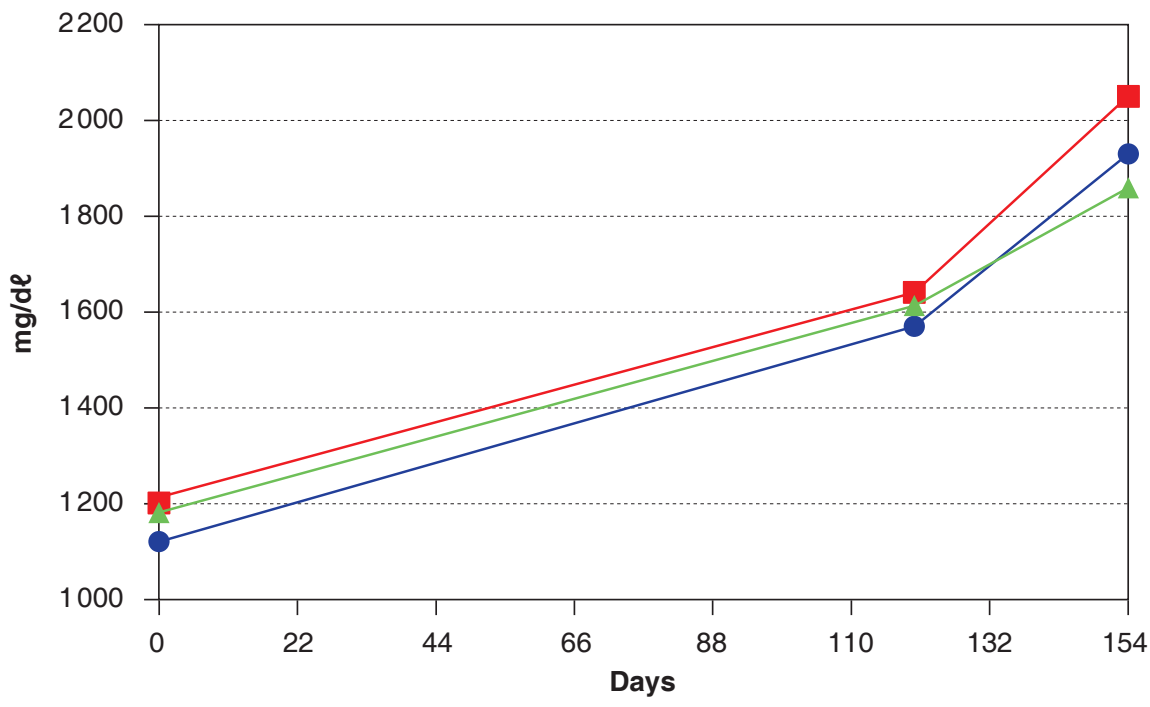

FIG. 8 IgG levels of the three experimental groups at Days 0,120 and 154 of the trial [normal range of IgG: 1700$2700 \mathrm{mg} / \mathrm{dl}$ (Coetzer et al. 1994)]

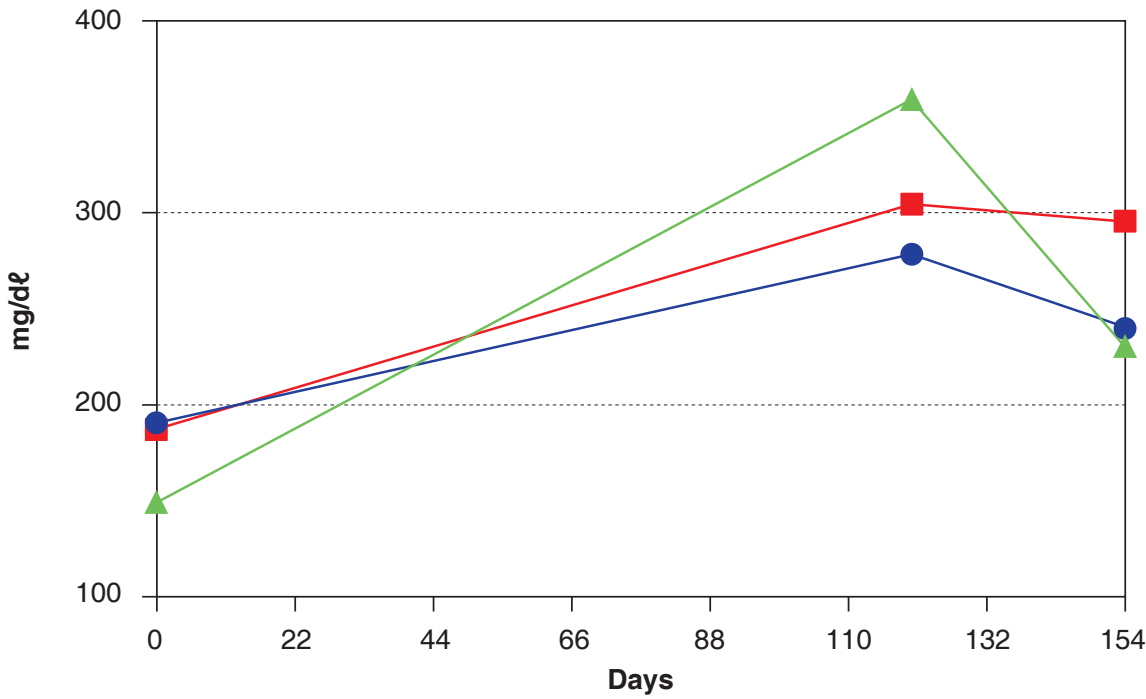

FIG. 9 IgM levels of the three experimental groups at Days 0,120 and 154 of the trial [normal range of IgM: 250$400 \mathrm{mg} / \mathrm{dl}$ (Coetzer et al. 1994)]

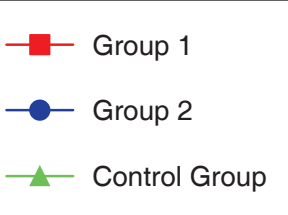

$$
\begin{aligned}
& - \text { Group } 1 \\
& - \text { Group } 2 \\
& - \text { Control Group }
\end{aligned}
$$


TABLE 6 Mean testosterone concentration of the three experimental groups at Day 154 of the trial

\begin{tabular}{|c|c|c|c|}
\hline & Group 1 & Group 2 & Control \\
\hline & \multicolumn{3}{|l|}{ Mean \pm SD } \\
\hline Testosterone $(\mathrm{nmol} / \ell)$ & $12.09 \pm 9.39$ & $14.4 \pm 9.27$ & $13.83 \pm 8.53$ \\
\hline
\end{tabular}

$\mathrm{SD}=$ Standard deviation

TABLE 7 Mean Brucella abortus antibody titres (CFT) of the three experimental groups 4 weeks after immunization with Brucella abortus Strain 19 vaccine $\AA$

\begin{tabular}{|l|l|l|l|}
\hline \multirow{4}{*}{ Brucella antibodies (IU) } & Group 1 & Group 2 & \multicolumn{2}{l|}{ Control } \\
\cline { 2 - 4 } & Mean \pm SD & $249.00 \pm 203.37$ & $278.18 \pm 205.87$ \\
\cline { 2 - 4 } & $269.64 \pm 198.87$ & \\
\hline
\end{tabular}

$\mathrm{SD}=$ Standard deviation

TABLE 8 Mean skin thickness of the three experimental groups before and after intradermal injection with Brucellergene OCB®

\begin{tabular}{|c|c|c|c|c|c|c|}
\hline \multirow[b]{4}{*}{ Skin thickness $(\mathrm{mm})$} & \multicolumn{2}{|l|}{ Group 1} & \multicolumn{2}{|l|}{ Group 2} & \multicolumn{2}{|l|}{ Control } \\
\hline & Before & After & Before & After & Before & After \\
\hline & \multicolumn{6}{|l|}{ Mean \pm SD } \\
\hline & $10.68 \pm 1.98$ & $13.73 \pm 2.28$ & $10.40 \pm 2.22$ & $13.68 \pm 1.49$ & $11.64 \pm 2.18$ & $14.69 \pm 2.41$ \\
\hline
\end{tabular}

$\mathrm{SD}=$ Standard deviation

\section{Immune status of the calves}

Using a serum screening dilution of 1:20, all animals in the three groups determined were positive for antibodies against IBR.

Before the immunization with Brucella abortus Strain 19 all the animals tested negative for $B$. abortus antibodies. The antibody titres against $B$. abortus were similar in the three groups one month after the immunization of the calves (Table 7). No statistical significant difference was found between the three experimental groups.

The results of the Brucella protein allergen skin test showed no statistical significant differences between the groups when skin thickness was measured $72 \mathrm{~h}$ after the intradermal administration of the antigen Brucellergene OCB $尺$ (Table 8).

With the "Lymphocyte transformation test", the control group showed more transformation at Day 120 after the challenge with the mitogen, Concanavilin $A$, but due to a very large standard deviation the difference was not statistically significant. Results are presented as a stimulation index (SI), where $\mathrm{SI}=$ mean counts per min of test sample/mean counts per min of unstimulated control. A SI higher than 2 was considered to be an indication of Concanavilin A-induced proliferation (Fig. 7).

Mean IgG titres in all three groups increased consistently during the molasses feeding trial (Fig. 8). Mean IgM concentrations increased after the start of molasses feeding at 4 months, but decreased slightly when determined again at 5 months into the trial (Fig. 9). Only slight variations occurred between the groups. No statistical significant differences were detected between the three experimental groups.

\section{Post mortem analyses}

Mean carcass mass of each group is shown in Table 9. No significant differences were found between groups.

No noteworthy macro- or microscopic lesions were detected in the organs/tissues.

All calves in the control group tested negative for $B$. abortus organisms on culture. Brucella abortus was cultured in the left pre-scapular lymph node of one animal in Group 2 and two animals in Group 1. 
Molasses as cause of "endocrine disruptive syndrome" in calves

TABLE 9 Average carcass mass of the three experimental groups

\begin{tabular}{|c|c|c|c|}
\hline & Group 1 & Group 2 & Control \\
\hline & \multicolumn{3}{|l|}{ Mean \pm SD } \\
\hline Carcass mass (kg) & $134.64 \pm 23.99$ & $145.3 \pm 25.88$ & $141.91 \pm 21.04$ \\
\hline
\end{tabular}

$\mathrm{SD}=$ Standard deviation

TABLE 10 Mean concentrations of $\mathrm{Cu}, \mathrm{Fe}, \mathrm{Zn}$ and $\mathrm{Mn}$ in liver samples

\begin{tabular}{|c|c|c|c|c|}
\hline & Group 1 & Group 2 & Control Group & \multirow{2}{*}{$\begin{array}{l}\text { Normal range in } \\
\text { cattle }^{*}\end{array}$} \\
\hline & \multicolumn{3}{|l|}{ Mean \pm SD } & \\
\hline $\begin{array}{l}\mathrm{Cu}(\mathrm{mg} / \mathrm{kg} \mathrm{WM}) \\
\mathrm{Fe}(\mathrm{mg} / \mathrm{kg} \mathrm{WM}) \\
\mathrm{Zn} \mathrm{(mg/kg} \mathrm{WM)} \\
\mathrm{Mn}(\mathrm{mg} / \mathrm{kg} \mathrm{WM})\end{array}$ & $\begin{array}{c}223.3 \pm 57.1 \\
40.4 \pm 9.4 \\
31.9 \pm 8.0 \\
2.9 \pm 0.3\end{array}$ & $\begin{aligned} 218.2 & \pm 39.3 \\
40.8 & \pm 3.8 \\
33.8 & \pm 8.1 \\
2.9 & \pm 0.5\end{aligned}$ & $\begin{array}{c}189.6 \pm 40.3 \\
40.5 \pm 9.8 \\
35.8 \pm 11.5 \\
2.8 \pm 0.4\end{array}$ & $\begin{array}{l}25-100 \\
45-300 \\
25-100 \\
2.5-6\end{array}$ \\
\hline
\end{tabular}

* Mineral levels in animal health (Puls 1994)

$\mathrm{WM}=$ Wet mass

$\mathrm{SD}=$ Standard deviation

The mean liver $\mathrm{Cu}, \mathrm{Fe}, \mathrm{Zn}$ and $\mathrm{Mn}$ concentrations for each group were calculated (Table 10). No relevant differences were found in the levels of these trace elements between the three groups.

\section{DISCUSSION}

Even though endocrine disrupting activity was detected in laboratory tests, these could not be reproduced in calves under experimental conditions. This illustrates that in vitro/in vivo comparisons can be misleading. In vitro assays do not always reliably predict the in vivo outcome, due to differences in metabolic capabilities of the test systems (and lack of in vivo pharmacokinetics and pharmacodynamics) and the diverse range of mechanisms by which endocrine disrupting chemicals may act (Clode 2006).

The feeding of molasses to calves has been reported by farmers to decrease production, but no significant differences between the study groups were detected in this study. During this feeding trial, calves from the three groups were kept in similar facilities, under the same conditions and fed diets with comparable composition regarding energy, protein and minerals (Tables 2 and 3). Drinking water parameters were also within normal limits. Although it would seem that Group 1 had a lower mean mass gain (compared to the other two groups) (Fig. 4), a significant difference only occurred at 4 months of molasses feeding. Considering that this was the only significant difference during the whole feeding trial, it is unlikely that this could be attributed to molasses in the feed. Although the calves from Group 2 exhibited a higher incidence of diarrhoea when compared with the other two groups (Fig. 1), it did not appear to affect their mass gain over the whole feeding period. As the results of faecal samples, submitted for bacterial culture and virus particle identification as well as screening for coccidial oocysts and helminth eggs, were negative, the diarrhoea was considered to be of dietary or metabolic origin.

The mean mass of the three experimental groups at Week 24 of the trial (when the calves were between 30 and 32 weeks of age) ranged from $243-261 \mathrm{~kg}$ (Fig. 2). Although these Holstein calves were weaned of milk within days of birth, their masses were comparable with the national average weaning mass of Bonsmara calves, a beef breed known for high weaning mass (220 kg at 205 days of age) (Agricultural Research Council, Livestock Business Unit 2006).

The farmers also reported increased reproductive disorders with poor conception, and high rates of resorption of foetuses and abortions, which were attributed to an "endocrine disruptive syndrome". Since the animals used in the feeding trial were bull calves, only certain parameters could be evaluated to detect reproductive disorders, viz., testosterone levels and the morphology and histology of the male reproductive organs. No significant difference was detected between the three groups with respect to testosterone concentrations (Table 6) and repro- 
ductive organs of the bull calves from the three groups showed no visible macro- or microscopical abnormalities.

The farmers also highlighted apparent immune incompetence/breakdown in their herds resulting in calf diarrhoea, verminosis, relapses of protozoal diseases in previously immunocompetent animals and pneumonia caused by various pathogens. In the current study, calves from the three experimental groups were considered to be immunocompetent. When tested for IBR antibodies at 4 months into the feeding trial, after being vaccinated at a very young age at the rearing facility, all the animals showed positive titres. When challenged with $B$. abortus vaccine, all the animals seroconverted and the three experimental groups showed similar antibody titres against $B$. abortus one month after the immunization (Table 7). In South Africa, titres of 30 $\mathrm{IU} / \mathrm{ml}$ or higher are considered positive in those animals that have been vaccinated between 4 and 8 months of age (Coetzer et al. 1994).

While all calves in the control group tested negative for $B$. abortus organisms on culture, only one animal from Group 2 and two animals from Group 1 tested positive. However, these results cannot be regarded as indicative of immune incompetence. In addition, immunoglobulin concentrations in the three groups showed no significant differences. Whereas IgG titres increased consistently during the molasses feeding trial (Fig. 8), most probably due to natural exposure to different pathogens in the environment, mean IgM concentrations increased at 4 months of molasses feeding, but decreased slightly when determined again at 5 months (Fig. 9). The lymphocyte transformation test performed at 4 months also corroborated the immune competency of the animals in the three experimental groups (Fig. 7).

Only three calves became sick during the trial, one calf from the control group developed a left sided abomasal displacement, which is not an infectious disease. One calf, from Group 1, was hospitalized due to severe persistent diarrhoea and another animal from Group 1 was treated for an upper respiratory tract infection, but both recovered.

Thus, all the parameters measured, indicate that the calves' immune response was not affected. Immunosuppression could, therefore, not be confirmed in the molasses fed calves.

Various mineral imbalances observed in the field were also attributed to the "endocrine disruptive syndrome". Although mean liver Cu concentrations in the three groups were higher than the normal range for cattle (Table 10), the concentrations did not reach toxic levels (250-800 mg/kg) (Puls 1994) and is ascribed to the high dietary Cu levels fed during the trial (Table 3 ). These results not only contradict reports of $\mathrm{Cu}$ deficiencies on the affected farms, but also molasses feeding experiments conducted in the past. Beames (1959) fed different rations to three groups of Hereford heifers and concluded that the two groups of animals receiving molasses as a supplement showed significantly depleted liver $\mathrm{Cu}$ concentrations when compared to a group of heifers receiving no molasses supplement. He concluded that the reduction of $\mathrm{Cu}$ reserves in the molasses-fed groups could be explained on the basis of high sulphur concentrations and a subsequent copper-molybdenum-inorganic sulphate interaction. Arthington \& Pate (2002), performed experiments on Brahman heifers and compared liver Cu concentrations between animals given corn vs. molasses supplements. Their results indicated that components in molasses-based supplements decreased the accumulation of $\mathrm{Cu}$ in the liver of beef heifers and they suggested that selenium and molybdenum components in molasses could be partly responsible for this decrease.

Although dietary levels of $\mathrm{Fe}$ were considered adequate (100-500 mg/kg)(Puls 1994), liver Fe concentrations in the three experimental groups were slightly lower than the normal range (Table 3 ), but did not reach deficient levels for cattle $(<30 \mathrm{mg} / \mathrm{kg})$ (Puls 1994). Iron deficiency is associated with anaemia, reduced growth, poor immune function and weakness (Graham 1991; Puls 1994). During the trial, no abnormalities in the haematology parameters were noticed and growth rate and immune function were also as expected.

Despite goitre being reported by the farmers manifesting as enlarged and/or cystic thyroids, no abnormalities were detected during macro- and microscopical examination of the thyroid glands of the animals from the three experimental groups. An assessment of thyroid hormone status $\left(T_{3}\right.$ and $\left.T_{4}\right)$ was also performed in the calves at four different times during the feeding trial (Fig. 6 and 7). The mean $\mathrm{T}_{3}$ concentrations of the three groups showed similar curves and even though animals in Group 1 showed a slightly lower mean $T_{4}$ concentration compared to the other two groups at 3 months after commencement of molasses feeding, no statistical significant difference could be demonstrated. An appreciable decrease in mean $\mathrm{T}_{4}$ concentration, although not 
statistically significant, occurred in the control group from the initial bleeding before molasses feeding commenced up to 3 months of molasses feeding.

Under the conditions of the present study, the two batches of molasses investigated induced no endocrine disruptive or immunosuppressive effects in the Holstein bull calves. It can therefore be concluded that these two batches of molasses per se were not deleterious when fed to calves.

\section{ACKNOWLEDGMENTS}

We thank the South African Sugar Association and the National Research Foundation for funding the trial. We also express our gratitude to the following people and institutions who performed various analyses during the trial and who also gave valuable input throughout the project: Prof. C. Cruywagen, University of Stellenbosch; Prof. L. Guillette Jr, University of Florida, USA; Dr G. Rottinghaus, Columbia University, USA; Dr M. Estes, Texas A \& M University, USA; Mr C. von Brandis; Proff. J. Lawrence, H. Bertschinger and J. Godfroid, and Dr J. Crafford, University of Pretoria; Mario Smuts, El-Maré Kilian, Roland Auer and the staff of the University of Pretoria's Biomedical Research Centre; Elsbé Myburgh and staff of the Section of Clinical Pathology, University of Pretoria; Elise Ferreira, UP Nutrilab; Drs A. Michell and M. van Kleef, OVI; Prof. F. Steyn Jr, North-West University; the Institute for Soil, Climate and Water, and the Sugar Milling Research Institute.

\section{REFERENCES}

ALTON, G.G., JONES, L.M., ANGUS, R.D. \& VERGER, J.M. (Eds). 1988. Techniques for the Brucellosis laboratory. Paris: Institut National de la Recherche Agronomique.

AGRICULTURAL RESEARCH COUNCIL (ARC). 2006. Livestock Business Unit. Annual Report 2005/2006. National Beef Cattle Improvement Scheme. Pretoria.

ARTHINGTON, J.D. \& PATE, F.M. 2002. Effect of corn- vs. molasses-based supplements on trace mineral status in beef heifers. Journal of Animal Science, 80:2787-2791.

ASSOCIATION OF OFFICIAL ANALYTICAL CHEMISTS (AOAC). 2000. Official methods of analysis, 17th ed. Maryland, USA: Association of Official Analytical Chemist, Inc.

BEAMES, R.M. 1959. A note on the effect of molasses on liver copper concentrations in cattle. Journal of Agricultural Sciences, 16:233-237.

BREVINI, T.A.L., CILLO, F., ANTONINI, S. \& GANDOLFI, F. 2005. Effects of endocrine disrupters on the oocyte and embryos of farm animals. Reproduction in Domestic Animals, 40:291-299.

CLODE, S.A. 2006. Assessment of in vivo assays for endocrine disruption. Best Practice \& Research Clinical Endocrinology \& Metabolism, 20:35-43.
COETZER, J.A.W., THOMSON, G.R. \& TUSTIN, R.C. (Eds). 1994. Infectious diseases of livestock with special reference to Southern Africa, $1^{\text {st }}$ ed. Cape Town: Oxford University Press.

COHEN, J. 1988. Statistical power analysis for the behavioral sciences, $2^{\text {nd }}$ ed. Hillsade, New Jersey: Lawrence Erlbaum Associates Inc.

COLBORN T., DUMANOSKI D. \& MYERS J. P. 1996. Our stolen future. New York: Plume Printing.

COLBORN, T., VOM SAAL, A.M. \& SOTO, A.M. 1993. Developmental effects of endocrine disrupting chemicals in wildlife and humans. Environmental Health Perspectives, 101:378384.

CRISP, T.M., CLEGG, E.D., COOPER, R.L., WOOD, W.P., ANDERSON, D.G., BAETCKE, K.P., HOFFMAN, J.L., MORROW, M.S., RODIER, D.J., SCHAEFFER, J.E., TOVART, L.W., ZEEMAN, M.G. \& PATEL, Y.M. 1998. Environmental endocrine disruption: an effect assessment and analysis. Environmental Health Perspectives, 106:11-56.

EERTMANS, F., DHOOGE, W., STUYVAERT, S. \& COMHAIRE, F. 2003. Endocrine disruptors: effects on male fertility and screening tools for their assessment. Toxicology in vitro, 17: 515-524.

GIRON, H.C. 1973. Comparison between dry ashing and wet digestion in the preparation of plant material for Atomic Absorption analysis. Atomic Absorption Newsletter, 12:28-29.

GRAHAM, T.W. 1991. Trace element deficiencies in cattle. The Veterinary Clinics of North America. Food Animal Practice, 7:153-215.

GRAY, L.E. Jr, KELCE, W.R., WIESE, T., TYL, R., GAIDO, K., COOK, J., KLINEFELTER, G., DESAULNIERS, D., WILSON, E., ZACHAREWSKI, T., WALLER, C., FOSTER, P., LASKEY, J., REEL, J., GIESY, J., LAWS, S., McLACHLAN, J., BRESLIN, W., COOPER, R., DI GIULIO, R., JOHNSON, R., PURDY, R., MIHAICH, E., SAFE, S. \& COLBORN, T. 1997. Endocrine Screening Methods Workshop report: detection of estrogenic and androgenic hormonal and anti-hormonal activity for chemicals that act via receptor or steroidogenic enzyme mechanisms. Reproductive Toxicology, 11:719-750.

GUILLETTE, L.J. Jr. 2000a. Contaminant-induced endocrine disruptors in wildlife. Growth Hormone \& IGF Research, B: S45-S50.

GUILLETTE, L.J. Jr. 2000b. Organochlorine pesticides as endocrine disruptors in wildlife. Central European Journal of Public Health, 8:34-35.

IPCS (International Programme on Chemical Safety) STEERING GROUP 1998. Joint IPC/OECD Scoping Meeting on Endocrine Disruptors, 16-18 March 1998, Washington, DC, USA.

ISHIHARA, A., SAWATSUBASHI, S. \& YAMAUCHI, K. 2003. Endocrine disrupting chemicals: interference of thyroid hormone binding to transthyretins and to thyroid hormone receptors. Molecular and Cellular Endocrinology, 199:105-117.

KAVLOCK, R.J., DASTON, G.P., DEROSA, C., FENNER-CRISP, P., GRAY, L.E., KAATTARI, S., LUCIER, G., LUSTER, M., MAC, M.J., MACZKA, C., MILLER, R., MOORE, J., ROLLAND, R., SCOTT, G., SHEEHAN, D.M., SINKS, T. \& TILSON, H.A. 1996. Research needs for risk assessment of health and environmental effects of endocrine disruptors: a report of the U.S. EPA-sponsored workshop. Environmental Health Perspectives, 104:715-740.

LAMB, J.C. 1996. Argument for the motion that endocrine disruptors pose a major risk to human health. Toxicology Letters, 88:12-13. 
LANGER, P., TAJTAKOVA, M., FODOR, G., KOCAN, A., BOHOV, P., MICHALEK, J. \& KREZE, A. 1998. Increased thyroid volume and prevalence of thyroid disorders in an area heavily polluted by polychlorinated biphenyls. European Journal of Endocrinology, 139:402-409.

LI, M.H. \& HANSEN, L.G. 1996. Enzyme induction and acute endocrine effects in prepubertal female rats receiving environmental PCB/PCDF/PCDD mixtures. Environmental Health Perspectives, 104:712-722.

LIPPMAN, M. \& HUFF, K. 1976. A demonstration of androgen and estrogen receptors in a human breast cancer using a new protamine sulfate assay. Cancer, 38:868-874.

MAUE, A.C., WATERS, W.R., PALMER, M.V., WHIPPLE, D.L., MINION, F.C., BROWN, W.C. \& ESTES, D.M. 2004. CD80 and CD86, but not CD154, augment DNA vaccine-induced protection in experimental bovine tuberculosis. Vaccine, 23: 769-779.

McDONALD, P., EDWARDS, R.A., GREENHALG, J.F.D. \& MORGAN, C.A. 1995. Animal nutrition, $5^{\text {th }}$ ed. Harlow: Longman Scientific and Technical.

MEIJER, G.A.L, DE BREE, J., WAGENAAR, J.A. \& SPOELSTRA, S.F. 1999. Sewerage overflows put production and fertility of dairy cows at risk. Journal of Environmental Quality, 28: 1381-1383.

NORRIS, D.O. \& CARR, J.A. 2006. Endocrine disruption. Biological bases for health effect in wildlife and humans. New York: Oxford University Press.

PERRY, T.W., CULLISON, A.E. \& LOWREY, R.S. 1999. Feeds and feeding, $5^{\text {th }}$ ed. Upper Saddle River, N.J.: Prentice Hall.

POOL, E.J., JOHAAR, G., JAMES, S., PETERSEN, I. \& BOUIC, P.J. 1998. The detection of pyrogens in blood products using an ex-vivo whole blood culture assay. Immunoassay, 19:95111.

POOL, E.J., ROBSON, P.J., SMITH, C., VAN WYK, J.H. \& MYBURGH, K.H. 2002. In vitro interleukin-6 release in whole blood cultures in samples taken at rest from triathletes and professional rugby players. European Journal of Applied Physiology, 87:233-237.

PULS, R. 1994. Mineral levels in animal health: diagnostic data, $2^{\text {nd }}$ ed. Clearbrook: Sherpa International.

RHIND, S.M. 2002. Endocrine disrupting compounds and farm animals: their properties, actions and routes of exposure. Domestic Animal Endocrinology, 23:179-187.

RHIND, S.M. 2005. Are endocrine disrupting compounds a threat to farm animal health, welfare and productivity? Reproduction in Domestic Animals, 40:282-290.

STATSOFT, INC. 2005. STATISTICA (data analysis software system), version 7.1. http://www.statsoft.com

SWEENY, T. 2002. Is exposure to endocrine disrupting compounds during fetal/post-natal development affecting reproductive potential of farm animals? Domestic Animal Endocrinology, 23:203-209.

TURQUE, P.T., PALMIER, K., LE MEVEL, S., ALLIOT, C. \& DEMENEIX, B. 2005. A rapid, physiologic protocol for testing transcriptional effects of thyroid-disrupting agents in premetamorphic Xenopus tadpoles. Environmental Health Perspectives, 113:1588-1593.

VAN KLEEF, M., MacMILLAN, H., GUNTER, N.J., ALLSOP, B.A., SHKAP, V. \& BROWN, W.C. 2000. Identification of Cowdria ruminantium antigens that stimulate proliferation of lymphocytes from cattle immunized by infection and treatment or with inactivated organisms. Infection and Immunity, 68:603-614.

VAN WYK, J.H., POOL, E.J. \& LESLIE, A.J. 2003. The effects of anti-androgenic and estrogenic disrupting contaminants on breeding gland (Nuptial Pad) morphology, plasma testosterone levels and plasma vitellogenin levels in male Xenopus laevis (African clawed frog). Archives of Environmental Contamination and Toxicology, 44:247-256. 